\title{
LOCAL IgG SYNTHESIS IN THREE PEDIATRIC PATIENTS WITH CUBAN EPIDEMIC NEUROPATHY
}

\section{ALBERTO DORTA-CONTRERAS*, ERIC MARTINEZ TORRES **, CARLOS DOTRES-MARTINEZZ* *}

\begin{abstract}
Three pediatric patients with Cuban epidemic neuropathy were studied. Cerebrospinal fluid and sera were simultaneously obtained. Albumin and IgG were quantified by immunodifusion. Albumin quotient and local synthesis of IgG were calculated by Reiber/Felgenhauer formula. A patient with optic neuritis had a dysfunction of the blood-cerebrospinal fluid barrier. All the group had local synthesis of IgG.
\end{abstract}

KEY WORDS: Cuban epidemic neuropathy, optic neuritis, peripheral neuropathy, cerebrospinal fluid, intrathecal synthesis.

\section{Síntesis local de IgG en tres pacientes pediátricos com neuropatía epidémica cubana}

RESUMEN - Se estudiaron tres pacientes pediátricos con neuropatia epidémica cubana. Se obtuvieron suero y liquido cefalorraquídeo simultaneamente. Se cuantificaran los niveles de albúmina e IgG por inmunodifusion radial. Se calculó la razón albúmina y la fórmula de Reiber/Felgenhauer. Un paciente con neuritis óptica tuvo una disfunción de la barrera sangre-líquido cefaloraquídeo. Todo el grupo tuvo síntesis local de IgG.

PALABRAS CLAVES: neuropatía epidémica cubana, neuritis óptica, neuropatía periférica, líquido cefalorraquídeo, JgG, albúmina, síntesis intratecal.

The etiology of the Cuban epidemic neuropathy (CEN) remains unknown. PAHO's report,5 has described it as being of multifactorial etiology, whereas involvement of nutritional deficit in combination with a neurotoxic and/or viral factor has been evoked.

The aim of this paper is to present the evidence of the intrathecal IgG synthesis in three pediatric patients with CEN.

\section{PATIENTS}

Sera and cerebrospinal fluid (CSF) from three pediatric patients suffering from symptoms of CEN were taken. The diagnosis of CEN was made by clinical criteria according to PAHO's Expert Committee.

CEN has two main presentations: the first one, an optic neuritis and a second form as peripheral neuropathy. Optic neuritis is retrobulbar, the optic nerve head appears normal. The visual acuity is decreased, and there is abnormal color perception, an afferent pupillary defect, and always a central scotoma.

Peripheral neuropathy produces a motor neuropathy with mild sensory impairment. The distribution of symmetrical distal weakness, with foot drop or wrist drop, paresthesias in the feet and legs. Sensation is decreased and the tendon reflexes are depressed. Cranial nerve involvement is unusual and the CSF protein content is normal, helping to differentiate from Guillain-Barre's syndrome.

*Laboratorio Inmunología, Hospital Pediátrico San Miguel, Ciudad de La Habana, Cuba; **Hospital Wiliam Soler, Ciudad de La Habana, Cuba. Aceite: 16-setembro-1995.

Dr. Alberto Dorta-Contreras - Laboratorio Inmunologia, Hospital Pediátrico San Miguel - Apartado 10049 11000 Ciudad de La Habana - Cuba. 


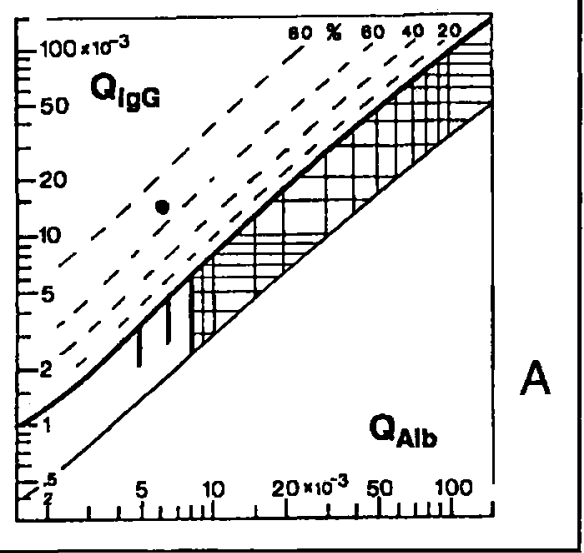

A) Patient 1. Age: 12 years old. Qlb and $Q I g G$ of the Patient I with optic neuritis. QAlb $<6.5$ age dependent limit, i.e. no blood/CSF barrier dysfunction and an additional intrathecal synthesis of $\lg G$.

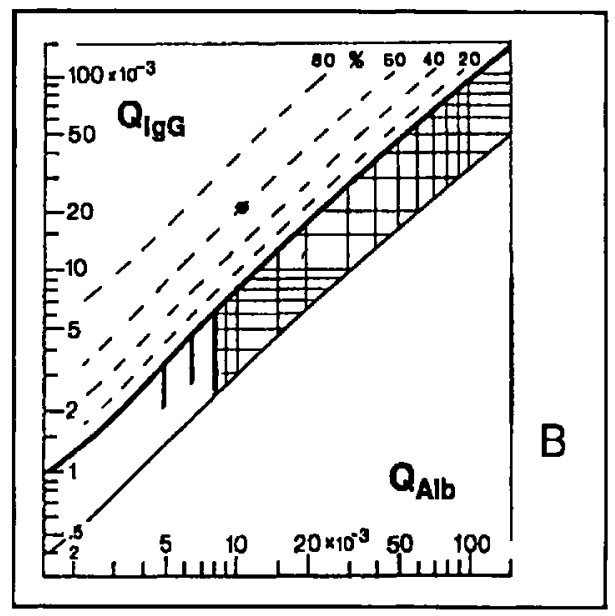

B) Patient 2. Age: 6 years old. QAlb and QIgG of Patient 2 with optic neuritis. QAlb>5, age dependent limit. This patient has a blood/CSF barrier dysfunction and an additional intrathecal synthesis of $\mathrm{Jg} G$.

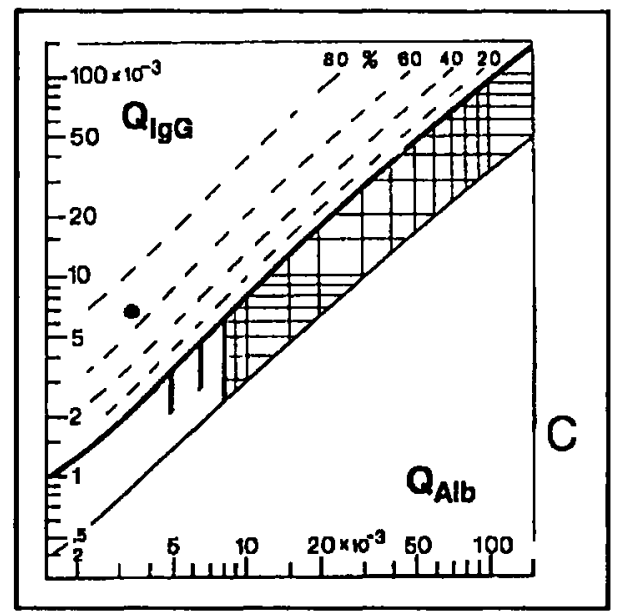

C) Patient 3. Age: 10 years old QAlb and QIgG of Patient 3 with peripheral neuropathy. In contrast to Patient 2, this patient has normal QAlb ( $Q A l b<5$, age dependent limit) and an additional local synthesis of $\operatorname{Ig} G$

Fig 1. Reiber/Felgenhauer quotient diagram.

In the diagram, QIgG (IgGCSF/IgGSERUM) is shown as a function of Qalb (AlbuminCSF/AlbuminSERUM) representing the blood/CSF barrier function ${ }^{7,8}$. Below the discrimination line (fitted by a hyperbolic curve) the fraction in CSF is primary blood-derived. Above the discrimination line, an increasing contribution of the locally CNS synthesized $\lg G$ can be demonstrated (given as a percent of locally synthesized $\lg G$ of the corresponding total CSF concentration). The dashed lines represent the percentile curves of local $\mathrm{lg} G$ synthesized in the central nervous system. 
Patient 1. Female. She had 12 years old. Had optic neuritis. CSF analysis: colorless, transparent, non cells, normal CSF protein content, normal glucose concentration. Bacteria and virus were not found by conventional microbiology and virology tests. No oligoclonal bands was performed.

Patient 2. Female. She had 6 years old. Had optic neuritis. CSF analysis: colorless, transparent, non cells, normal CSF protein content, normal glucose concentration. Bacterial and virus analysis were negative. No oligoclonal bands was performed.

Patient 3. Male. He had 10 years old. Had peripheral neuropathy. CSF analysis: colorless, transparent, $4 \times 10^{9}$ cells $/ \mathrm{L}$; both nomal protein and glucose concentration. No bacteria or virus were found. No oligoclonal bands was performed.

\section{METHODS}

IgG and albumin were measured in serum and CSF by NOR and LC Partigen immunodifussion plates, respectively (Behringwerke AG, Marburg).

The calculations were performed by the Neuroimmunolabi .IgG intrathecal synthesis was calculated by the improved' Reiber/Felgenhauer formula".

Albumin quotient (Qalb = AlbCSF / AlbSERUM) was calculated.

\section{RESULTS}

Fig 1 shows the Reiber/Felgenhauer quotient graph. The black points indicate each studied patient. All the three patients were placed over the reference curve. It means a local synthesis of IgG.

The Patient 2 (Fig lb) has a blood/CSF barrier dysfunction and an additional intrathecal synthesis of $\mathrm{IgG}$.

\section{DICUSSION}

The diagnosis of CEN was made by PAHO's Expert Committee. The diagnosis was performed during the outbreak of CEN. No other neurological disease were involved in the patients.

Albumin quotient (Qalb) is a measure of the blood-CSF barrier function. Albumin serve as a marker of the protein diffusion through this barrier because of its exclusive hepatic synthesis. Albumin also has not great variations between pathological and normal conditions and it does not change in CSF.

A patient with optic neuritis has blood-CSF dysfunction because its Qalb is greater than the Qalb age dependent limit. This phenomenon has been described in several adult patients with the optic neuritis form of $\mathrm{CEN}^{2}$.

The patients had local IgG synthesis according to Reiber/Felgenhauer formula and diagram. In principle, one must differentiate between two cases of IgG local synthesis: a first case, in which a biological agent would be the etiologic agent of the disease; and a second case, where secondary polyspecific immune reaction took place without a persistent antigen or corresponding clinical signs of a virus infection.

No infectious agent was isolated from CSF culture in our patients. The disease appears suddenly without clinical signs of a previous viral or bacterial infection.

On the other hand one must keep on mild that local synthesis in the brain is a long process, often occurring over many years ${ }^{6}$ and it does not indicate precisely the acuity of the process.

It is not possible to establish that local IgG synthesis is a common characteristics of CEN because this paper shows the results of only three patients. Also a local IgG synthesis is a common mechanism in many neurological diseases but it do not indicate a common etioliogy.

The increased amounts of intrathecal IgG play a prominent role in inflammation and demyelination. This view is supported by the demyelination activity of aggregated IgG in form of immune complex in the peripheral nervous system ${ }^{3}$. 


\section{REFERENCES}

1. Dorta-Contreras AJ, Garcia-Fernandez L, Gil Chaviano M. Neuroimunolab: sistema para la evaluación de la respuesta inmune en el sistema nervioso central. Rev Cubana Invest Biomed 1991; 10:155.

2. Hernández A, León E, San Martin M, Alfonso A. Relations between the results of the immunologic and electrophysiologic studies on a group of patients with epidemic optic neuropathy (Abstract). Habana: Round table on the development of neuroscience in the Caribbean, 1993:3.

3. Krajewski S, Szablowska-Krajewska M. Disseminated vasculomyelopathy in the peripheral nervous system mediated by immune complexes (ICs). Neurol Sci 1986; 72:131-136.

4. Llanes G, Asher D, Brown P, Gadjdusek DC, Marquez M, Muci-Mendonza R, Roman GC, Silva JC, Spencer PS, Thylefors B. Neuropatia epidémica en Cuba. Bol Epidemiol OPS 1993; 14:1-4.

5. OPS. Neuropatia epidémica cubana: una actualización. Bol Epidemiol OPS 1994; 15:7.

6. Prange H, Moskophidis M, Schipper HI, Mueller F. Relationship between neurological features and intrathecal synthesis of IgG antibodies to Treponema pallidum in untreated and treated human neurosyphilis. J Neurol 1994; 230:241-252.

7. Reiber H. Flow rate of cerebrospinal fluid (CSF): a concept common to normal blood-CSF barrier function and to dysfunction in neurological diseases. J Neurol Sci 1994; 122:189-203.

8. Reiber H, Felgenhauer K. Protein transfer at the blood cerebrospinal fluid barrier and the quantititation of the humoral immune response within the central nervous system. Clin Chem Acta 1987; 163:319-328. 